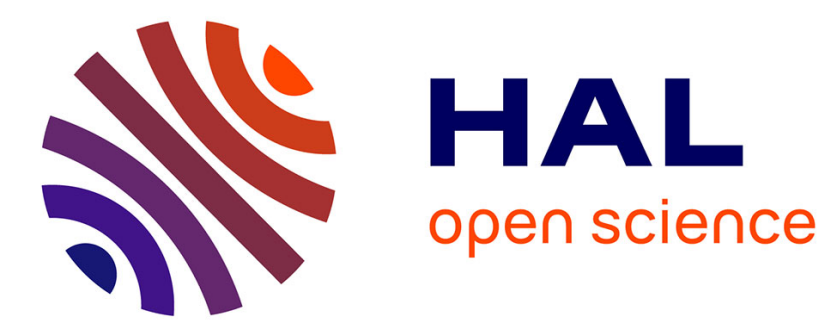

\title{
Data processing tool for calculation in dioid
}

\author{
Bertrand Cottenceau, Mehdi Lhommeau, Laurent Hardouin, Jean-Louis \\ Boimond
}

\section{To cite this version:}

Bertrand Cottenceau, Mehdi Lhommeau, Laurent Hardouin, Jean-Louis Boimond. Data processing tool for calculation in dioid. WODES'2000, Workshop on Discrete Event Systems, Aug 2000, Ghent, Belgium. pp.x-x. hal-00845037

\section{HAL Id: hal-00845037 https://hal.science/hal-00845037}

Submitted on 16 Jul 2013

HAL is a multi-disciplinary open access archive for the deposit and dissemination of scientific research documents, whether they are published or not. The documents may come from teaching and research institutions in France or abroad, or from public or private research centers.
L'archive ouverte pluridisciplinaire HAL, est destinée au dépôt et à la diffusion de documents scientifiques de niveau recherche, publiés ou non, émanant des établissements d'enseignement et de recherche français ou étrangers, des laboratoires publics ou privés. 


\section{DATA PROCESSING TOOL FOR CALCULATION IN DIOID}

Cottenceau Bertrand, Lhommeau Mehdi, Hardouin Laurent, Boimond Jean-Louis

LISA

62, Avenue Notre-Dame du Lac, 49000 ANGERS, FRANCE

hardouin@istia.univ-angers.fr

Keywords: Dioid, Timed Event Graph, Periodic Series

Abstract This note presents briefly a data processing tool to handle the periodic
series.

\section{Introduction}

The team $(\max ,+)$ of the INRIA Rocquencourt has developed a toolbox, integrated in software Scilab, for calculation in the dioids $(\max ,+)$ or $(\min ,+)$. We propose here to present a library of calculation for the periodic series in the dioid of formal series.

\section{DATA PROCESSING TOOL}

Let us recall that a timed event graph (TEG) is a timed Petri net whose each place has only one upstream transition and one downstream transition. The behavior of these graphs can be described by using one linear equations system into some particular dioids, for instance in the dioid of formal series such like the dioid $\mathcal{M}_{i n}^{a x} \llbracket \gamma, \delta \rrbracket$ (see [1]). The input/output behavior of TEG can then be described by a state representation $(X=A X \oplus B U, Y=C X)$ and/or a transfer matrix $H=C A^{*} B$ with $A^{*}=\bigoplus_{i \in \mathbb{N}} A^{i}$.

Each entries of this matrix is a periodic and causal series admitting a representation of the form: $s=p \oplus q r^{*}$ with $p=\bigoplus_{i=0}^{\alpha} \gamma^{n_{i}} \delta^{t_{i}}$, $q=\bigoplus_{j=0}^{\beta} \gamma^{N_{j}} \delta^{T_{j}}$ and $r=\gamma^{\nu} \delta^{\tau}$. The series is said proper if $\left(n_{\alpha}, t_{\alpha}\right) \leq$ $\left(N_{0}, T_{0}\right)$ and if $\left(N_{\beta}-N_{0}, T_{\beta}-T_{0}\right) \leq(\nu, \tau)$. A series admits a simplest periodic proper representation, called the canonical form of $s$. 
As an example, below we provide a TEG, its representation of state and its transfer matrix in dioid $\mathcal{M}_{i n}^{a x} \llbracket \gamma, \delta \rrbracket$.

$$
\begin{aligned}
& \left\{\begin{aligned}
X & =\left(\begin{array}{ccc}
\varepsilon & \delta & \varepsilon \\
\gamma & \varepsilon & \varepsilon \\
\gamma^{2} \delta^{2} & e & \varepsilon
\end{array}\right) X \oplus\left(\begin{array}{cc}
\gamma \delta & \varepsilon \\
\varepsilon & e \\
\varepsilon & \varepsilon
\end{array}\right) U \\
Y & =\left(\begin{array}{lll}
\varepsilon & \varepsilon & e
\end{array}\right) X
\end{aligned}\right. \\
& Y=\left(\gamma^{2} \delta \oplus \gamma^{3} \delta^{3}(\gamma \delta)^{*} \quad e \oplus \gamma \delta \oplus \gamma^{2} \delta^{3}(\gamma \delta)^{*}\right) U=H U . \\
& u_{1}
\end{aligned}
$$

Figure 1 GET example

In this context, the manipulation of elementary systems and the synthesis of correctors require data-processing tools in order to handle the periodic series. S. Gaubert [4] proposes a certain number of algorithms making it possible to calculate the sum, the product and the star of these series. In [2] we propose algorithms computing the inf and the residuation of these same series. There are two implementations of these algorithms, one developed in script Matlab and the other developed with language $\mathrm{C}++$. We also propose a module making possible to interface this latest library with Scilab. This software was used to calculate, for instance, the applications of the references [3]. All these tools are available on http://www.istia.univ-angers.fr/ hardouin.

\section{References}

[1] F. Baccelli, G. Cohen, G.J. Olsder, and J.P. Quadrat. Synchronization and Linearity: An Algebra for Discrete Event Systems. John Wiley and Sons, New York, 1992.

[2] B. Cottenceau. Contribution à la commande de systèmes à événements discrets : synthèse de correcteurs pour les graphes d'événements temporisés dans les diö̈des. Thèse de doctorat, Université d'Angers, France, 1999.

[3] B. Cottenceau, L. Hardouin, J.L. Boimond, and J.L. Ferrier. Synthesis of greatest linear feedback for timed event graphs in dioid. IEEE Trans. on Automatic Control, 44(6):1258-1262, June 1999.

[4] S. Gaubert. Théorie des systèmes linéaires dans les dioïdes. Thèse de doctorat, Ecole des Mines de Paris, Paris, 1992. 